\title{
Preface \\ to the \\ Paperback \\ Edition
}

I am writing this preface during the days of the COVID-19 pandemic, and my thoughts are therefore traveling back and forth from the distressing reality outside my sheltered study to the theoretical questions at the heart of this book. I cannot but ask myself how the one influences the other. I therefore end this section with some preliminary reflections on nationalism in the age of coronavirus.

It is impossible to predict where the world is heading, yet human nature is unlikely to change; hence it is quite safe to assume that questions of identity, self-expression, and self-rule will remain central to our personal and national ways of thinking. The recent coronavirus pandemic teaches us an interesting lesson: even in times of a global crisis, people tend to segregate themselves along national lines. Headlines these days show the global spread of the virus but then point to the disorganized nature of the political system in Italy, ponder about German obedience, compare the Chinese way of doing things with the American way, and wonder about the British decision to put personal liberty before public health. Whatever the medical and political conclusions are, the correlation between national cultures and the structure and behavior of political institutions is more evident than ever.

The pandemic forced nation-states to step up to the challenge of offering functional solutions to a fast-spreading sense of helplessness. Consequently, the pendulum swinging between the national and the global poles comes closer to the national one. This does not mean that international cooperation will be put on hold. Quite the contrary. Nations share 
knowledge and help each other when necessary, but their focus will be the best interest of their own citizens. We are then in an age of nationalism, and attempts to rethink nationalism are more urgent than ever.

It has been over a year since this book was first published, and the political reality around the globe has taught us that the issues raised are going to stay with us for the foreseeable future. The crisis of liberalism and the return of nationalism is on everyone's mind. While liberals are on the defensive, nationalists feel safe that they have succeeded in dropping an anchor in the troubled political waters.

Leaders and social movements no longer shy away from using the language of nationalism. In fact, taking the national stand, more often than not, is seen as a virtue rather than a vice. Donald Trump did not miss this change of hearts, openly defining himself as a nationalist. A globalist, he said, "is a person that wants the globe to do well, frankly, not caring about our country so much. And you know what? We can't have that. ... You know, they have a word-it's sort of became old-fashionedit's called a nationalist. And I say, really, we're not supposed to use that word. You know what I am? I'm a nationalist, okay? I'm a nationalist. Nationalist. Nothing wrong. Use that word. Use that word." ${ }^{1}$ His statement met harsh criticism. Some tried to claim that unlike Europe, the American ethos is the exact opposite of nationalism: that in its early days (before the French Revolution) America developed its identity on the basis of universal principles characteristic of the Enlightenment rather than on the basis of particular national traits or qualities.

We believe, Kim Holmes of the Heritage Foundation writes, that "Americans are different because our creed is both universal and exceptional at the same time. We are exceptional in the unique way we apply our universal principles. It doesn't 
necessarily mean that we are better than other peoples, though I think probably most Americans do believe they are. It's not only about bragging rights," she continues, "but rather, a statement of historical fact that there is something truly different and unique about the United States which becomes lost when talking in terms of nationalism." ${ }^{2}$ What would a French reply be? Are not liberté, égalité, and fraternité universal principles? Of course they are, but they were molded in a particular national form. They are therefore simultaneously French and universal-just as much as the biblical call "let my people go!" echoes far beyond the particular Jewish narrative. ${ }^{3}$

Contrary to what many believe, the problem with (or the power of ) nationalism is not its particularism but the ability to spread its influence across national borders. Both benevolent and malignant forms of nationalism are contagious. Fears regarding the spread of destructive nationalism have already been realized. In 2018 and 2019, we saw a massive growth in hate crimes and xenophobia. By the end of 2018, the European Union's Fundamental Rights Agency found that 89 percent of Jews living in Austria, Belgium, Denmark, Germany, France, Hungary, Italy, the Netherlands, Poland, Spain, Sweden, and the United Kingdom felt that anti-Semitism had increased in their countries over the past decade and believed that it presents a serious social challenge. Almost half of Jews worry about being insulted or harassed in public, and more than a third fear being physically attacked. ${ }^{4}$

Islamophobia has also spread across Europe and the United States. In March 2019, the Organisation of Islamic Cooperation (OIC) published its twelfth "observatory report," which lists anti-Muslim events between June 2018 and February 2019. Muslims, the report argues, are among the first victims of the rise of far-right extremism in Europe. In Austria, the Office for 
Documenting Islamophobia and Anti-Muslim Racism recorded an increase of approximately 74 percent in documented anti-Muslim acts. In France, the Collectif contre l'islamophobie en France reported an increase of 52 percent in Islamophobic incidents. In the United Kingdom, the number of cases recorded in official statistics rose by 17 percent. Finally, in the Netherlands, the Anti-discrimination Agencies announced that 91 percent of a total of 151 incidents of religious discrimination reported to the police were related to Muslims. Women constitute the majority of the victims of Islamophobia, especially when they wear headscarves. "Attacks against Muslim women range from verbal aggressions, denial of access to services, forced removal of the headscarf, and go as far as attempted rape" and physical attacks. ${ }^{5}$ In the United States, anti-immigrant, anti-Muslim, and anti-Semitic attitudes have become prevalent. Under the auspices of Trump, hate speech, racial hostility, and ethnic violence are spreading.

The brutal killing of George Floyd by a white police officer in Minneapolis instigated the most recent outcries against racism. Race relations became as volatile as they were in the 196os. Yet the rage over Floyd's murder marks a turning point: people were drawn to the streets, and suddenly more than one national voice echoed in the public sphere. Hatred and xenophobia met a firm demand for acceptance and inclusion. The two forms of nationalism - one conservative and exclusive, one progressive and inclusive-openly struggle for dominance. This clash is most obviously expressed by the toppling of statues. "In the United States, protesters first focused on Confederate monuments. But they have since cast a wider eye, including at former presidents like Andrew Jackson, a slave owner whose policies forced Native Americans from their land, and Woodrow Wilson, the architect of the League of Nations whose legacy has 
faced increasing scrutiny for his racist views and his resegregation of the federal work force." By the end of June 2020, Princeton University decided to remove the name of former US president Woodrow Wilson from a building on its campus because of his racist beliefs and policies, his barring of black students from Princeton while serving as its president, and approvingly speaking of the Ku Klux Klan. ${ }^{7}$ That very day, the lower house of the Mississippi state legislature passed a resolution that would remove the Confederate emblem - now viewed by many as a racist symbol-from the state flag.

These reevaluations of the nation's past and a redrawing of the line between shame and glory spread to other parts of the world, invigorating a debate over Europe's role in Africa. "In France many protesters focused on Jean-Baptiste Colbert, the 17 th-century statesman who is still celebrated for his lasting impact on France's political economy, but who was also the author of the Code Noir, the 1685 decree regulating slavery in the colonies.... A protester splattered red paint on a statue of Colbert in front of the National Assembly in Paris and wrote 'state Negrophobia' on its pedestal." Likewise, "a crowd in Bristol, England, toppled a statue of the 17th-century slave trader Edward Colston. In Antwerp, Belgium, the local authorities, responding to increasing protests, removed a statue of Leopold II, the Belgian king who ran an exploitative regime that led to the deaths of millions in what is now the Democratic Republic of Congo and whose ambitions set off Europe's scramble for African colonies." Those pulling down monuments of past oppressors are as concerned about their national narrative as those who strive to protect them. Their struggle attests to the fact that they wish to take responsibility for their past and to shape their future national narrative to be more just and inclusive. 
Struggles over national narratives teach us that despite the strengthening of xenophobic nationalism across Europe and Trumpism in the United States, liberal inclusive forms of nationalism are alive and kicking. The political and ideological reality is far more nuanced than it seems at first sight. In fact, I am ready to take a further step and argue that liberal nationalism is going to be the core of a new ideological convergence that is about to dominate the political discourse.

\section{Is Nationalism the Opposite of Patriotism?}

Though less noticeable and rarely falling under the definition of nationalism, numerous cases of moderate nationalism have emerged across the globe. The reason that this trend is less visible is that many moderate nationalists attempt to distance themselves from their rivals by adhering to an artificial distinction between nationalism and patriotism. President Macron of France is a good example: in a speech delivered to mark the centennial of the end of the First World War, Macron juxtaposed the universal values of the French Revolution with President Trump's selfish nationalism, calling nationalism "a betrayal of patriotism." Patriotism, he argued, "is exactly the opposite of nationalism." ${ }^{10}$ Macron made this distinction for the first time during his presidential campaign in an attempt to distance himself from his main rival, Marine Le Pen, president of the rightwing National Rally. In contrast with Le Pen's exclusionary nationalist policies, Macron offered an inclusive patriotism, declaring that he is "the president of all the people of France, the president of patriots faced by the menace of nationalists." 11

For Macron, patriotism has three defining features: (1) it is particularistic in the sense that it celebrates the national language, norms, traditions, values, and institutions; (2) it is 
inclusive in the sense that it applies to all citizens; and last but not least, (3) it advocates internationalism alongside a commitment to one's homeland. Nationalism, on the other hand, separates out citizens of different origins, highlighting the tensions between "us" and "them" as well as between the best interests of one's homeland and those of "others."

One could challenge Macron on semantic grounds. $\mathrm{He}$ clearly deviates from the traditional definitions of patriotism. The dictionary of the French Academy published in 1798 claimed that a "patriot" is someone who loves the fatherland and is dedicated to serving it. ("Celui, celle qui aime sa patrie, et qui cherche à lui être utile.") The historian Alphonse Aulard has argued that during the French Revolution, the term had two meanings: a person who loves his homeland and a person who desires "to organise his fatherland by means of liberty" - a definition that transformed the revolutionary act into a patriotic one. $^{12}$

In English, "patriotism" has a rather similar meaning. Webster's Dictionary defines it as "the love of one's native country (patria); a passion which leads a person to serve one's country with zeal." The Cambridge Dictionary states that patriotism is "the feeling of loving your country more than any other and being proud of it." "Nationalism" is defined by the same dictionary as "a great or too great a love of your own country." I assume that "too great a love" refers to an obsessive or zealous love.

Macron then seems to promote a semantic distinction grounded in no real difference. Both nationalism and patriotism are the fruits loving of one's own, which is one of the most natural human instincts: from parenthood to national love, we attach special importance to the magic pronoun "my." 13 Whether grounded in a social contract or in affections, the attachments and obligations that patriotism and nationalism 
produce are particular. The distinction, if there is one, may then refer to the kind of particularity in question. Macron would have liked patriotism not to be grounded in ethnic differences but rather in a civic state of affairs that grants all citizens, regardless of their origins, equal status and makes special attachments an expression of legal and contractual measures.

While in theory the distinction between contract (legal and constitutional)- and content (history, narrative, language, tradition)-based affiliations may work, in practice, even societies that are grounded in contractual terms easily slide from the universal to the particular. ${ }^{14}$ This has certainly been the case with French nationalism, which is grounded in universal principles as well as in a strong cultural, linguistic background and a very particular understanding of separation between a secular state and private religious beliefs.

While Macron would have liked such particularities to be of minor significance, he is defeated by reality. From the point of view of minorities, especially Muslim minorities, French universalism is a culturally and religiously laden concept. "It is an ideal of a universal which is premised on the concept that there is one human race," says Achille Mbembe, a Cameroonian expert on postcolonial history and France. "But the French confuse the horizon with the existing reality. There's a huge gap."15

The way Frenchness is perceived depends then on where you stand. In a speech delivered in Marseille, one of France's most diverse cities with a mixed population of veterans, immigrants, and refuge seekers, Macron offered his version: "When I look at Marseille I see the people of France. Look at them. They are here. They are proud. Proud of being French. Take a good look at them. Ladies and Gentlemen of the National Front: this is what it means to be proud to be French." ${ }^{16}$ Some of the residents of Marseille were less convinced. Marseille is "the world 
capital of apartheid," says Samia Ghali, the mayor of Marseille's fifteenth and sixteenth arrondissements and a national senator with the Parti Socialiste. We feel "alone in a world," she says. "People don't want to see us." ${ }^{17}$ Needless to say, feelings of estrangement are also common among many of the "ancient majority" (Jean-Pierre Raffarin called them "la France d'en haut"), ${ }^{18}$ who feel that Marseille is no longer the France they knew and who find the high level of diversity difficult to cope with. Denying this complexity made Marseille into a hotbed of the National Front.

Repeated failures show that civic, principle-basedcontract-grounded-patriotism cannot sustain itself on its own. The lines between inclusive patriotism and exclusive nationalism are being blurred in Germany, the United States, and most Nordic states, to mention just a few cases to which I shall shortly return. This teaches us that two of Macron's defining characteristics of patriotism are less obvious than he assumes. Both nationalism and patriotism are grounded in the particular and are less inclusive than some would like them to be.

The illusion that there could be no difference between the in-group and the out-group - that political systems are "difference-blind," treating individuals equally regardless of their particularities - leads moderate progressive forces to avoid two important challenges, and that puts them at a disadvantage. First, they are reluctant to discuss terms of membership. Both newcomers and veterans know that there are standards of acceptance, and they are keen to know who can join the group and on what terms. The answer "everybody can" is disingenuous and intimidating.

Second, the desire to be inclusive leads progressives not only to avoid questions of demarcation but also to sidetrack the most important challenge of all: how "others" who live among 
us ought to be treated. The answer to this question sketches the major difference between xenophobic and liberal nationalism. While xenophobic nationalism thrives on hatred and delegitimazation of "the other," liberal nationalism offers "the other" equal concern and respect. It is therefore important for liberal nationalists to have policies regarding membership and immigration while drawing a clear distinction between entry rights and a respectful attitude to "others" who live among us.

What then remains of Macron's distinction between patriotism and nationalism? Maybe the dispute over global solidarity. For Macron, patriots advocate internationalism, whereas nationalists endorse chauvinism, alongside egocentric and isolationist attitudes. Yet, foreign policy rarely falls into either of these extreme categories; it reflects national, social, and economic interests that can lead, at different times, to conflicting conclusions. When national interests overlap global ones, it is reasonable to tilt in the global direction; when such interests collide, national protectionist policies become popular; and in most cases, foreign policy is a mixture of both.

Here are some examples: President Xi of China is a defender of globalism and free trade, which are inseparable from his nationalist agenda. Nationalism and internationalism are intertwined in his ambitious "One Belt, One Road" vision that he believes will make China great again. $\mathrm{Xi}$ is a national-globalist who sees the interests of his country as being served by the proliferation of global trade and collaborations. Macron believes that being a member of the European Union is in France's best interest, so he is a national-regionalist, while Trump assumes that America has benefited less than it should from global trade agreements and therefore wishes to renegotiate them. In this spirit, he has restructured NAFTA. Now called the "United States-Mexico-Canada Agreement," it "updated the 
quarter-century-old NAFTA, with stronger protections for workers and the digital economy, expanded markets for American farmers and new rules to encourage auto manufacturing in North America." ${ }^{19}$ Neither Macron, Trump, nor Xi recoils from the international scene. All of them put their countries first and, in light of their analysis of their national interests, structure their foreign policies.

The real distinction then is not between narrow-minded nationalists and open-minded globalists but between different evaluations of costs and benefits of the complex interplay of national and global interests. As Stephen Walt rightly argues, "We live in a world of bristling nationalisms that are not going to change anytime soon"; we must, therefore, acknowledge that nationalism should be the basis on which to construct a realistic foreign policy. ${ }^{20}$

We may then conclude that the distinction between patriotism and nationalism is a bit too simplistic; it largely derives from a political need to distance oneself from one's political rivals. In France, the term "nationalism" was expropriated by the extreme right; hence Macron defines himself as a patriot. In the United States, "patriotism" is a term Democrats use; hence Trump defines himself as a nationalist.

Rather than hair-splitting between nationalism and patriotism, perhaps we should acknowledge the fact that, like other political theories, nationalism and patriotism bear a family resemblance and share a common ancestor. Both can turn malignant. Yet malignancy is not inevitable. The nation-state can be almost anything. "It can be fascist, or authoritarian. It can be totalitarian, or it can be democratic." ${ }^{21}$ Nationalism is a flirtatious ideology, happy to engage with others. It could end up with a variety of bedfellows. Liberal nationalism is one possible offspring-born out of a relationship with liberals, democrats, 
and progressive forces, it balances different, at times conflicting, values and borrows ideas from across the aisle. This mélange makes the nationalist element less prominent and harder to detect.

It is therefore easy to overlook the spread of moderate forms of nationalism, highlighting only its most extreme appearances: the emergence of a belligerent white supremacism, the flourishing of extreme right parties in many European countries, and the exceptional political power of Narenda Modi, Recep Tayyip Erdoğan, Vladimir Putin, and Benjamin Netanyahu. It is much more challenging to discern more moderate forms of nationalism. And yet, given the present political climate, it is important to urge progressive, social, liberal, and democratic parties not to surrender the national point of view. Maybe, rather than worrying why Trump defines himself as a nationalist, we should worry why progressives have not yet found a way to harness nationalism to their goals.

\section{The Age of Convergence}

The reemergence of nationalism is triggered by a set of social and economic crises characteristic of the twenty-first century. Hyperglobalism, neoliberalism, climate change, immigration waves, and finally the coronavirus pandemic rocked the political boat, revoking a process of legitimization of nationalism alongside a growing need to harness the state to promote and protect the well-being of two groups of citizens: today's needy (the infected, the pensioners, the unemployed, and low-income workers) and the needy of the future, exposed to unknown forthcoming dangers (from global warming to future pandemics).

This newly emerging "well-being coalition" serves national, social, and ecological ends. Its essence is simple. The nation- 
state should be an active player in defining and defending its borders and in providing its citizens greater support in good and bad times. Needs are translated into a political reality. In 2020 , before the coronavirus virus shook our world, new policies emerged in response to the immigration crisis, growing social inequities, and the warming of the planet. These could have been seen as separate issues, yet they have something in common: they teach individuals that they cannot control their destiny on their own, that they should not let their future be defined by laissez-faire policies, and that they need the state on their side-and for that purpose, they need political power. In many political systems this lead to the formation of wide, somewhat unexpected, ideological and political convergence. Here are some examples.

On the first day of 2020, Sebastian Kurz, the leader of the Austrian center right-wing party (the Austrian People's Party) entered into a coalition with the Greens, a coalition reflecting a convergence between social, environmental, and national ideologies. Its member parties joined hands in order to fulfill their promises to their voters on two major fronts: immigration and environmental policies. The coalition, so it was declared, is committed to the well-being of both present and future generations. This allowed it to solicit support among a wide range of constituents - from middle-aged, conservative voters to younger, more radical ones.

Yet Austria was not the first. Denmark led the way with an earlier appearance of the "well-being coalition." Prime Minister Mette Frederiksen, a Social Democrat, formed a government backed by the Socialist People's Party, the Red-Green Alliance, and the Social-Liberal Party, offering a firm position on climate change, generous welfare policies, and a hard line on immigration. This allowed Frederiksen to gather support from 
working-class and conservative voters alike, leaving the extreme right empty-handed.

Kurz and Frederiksen are not alone; other leaders are moving in the same direction. Upon his election, Stefan Löfven, the Social Democratic Swedish prime minister, formed a historic deal with the Centre, Liberal, and Green parties, linking traditional welfare policies with a firm commitment to fight global warming and a harsher line on immigration. Sweden seemed to be immune to nationalist anti-immigrant sentiments. For some years it wholeheartedly welcomed more refugees per capita than any other European state. Yet, the open-door policy backfired; it created social discontent among old-timers and newcomers alike, forcing Löfven to commit himself never to "go back to the mass immigration Sweden had in autumn 2015." What is necessary, he argued, is "a well-managed immigration policy that benefits those who are here." ${ }^{22}$ Like Frederiksen, Löfven is careful to respect existing immigrant communities, pledging to invest more resources in social and economic integration while narrowing the gateway and making entry far more difficult.

Ideological convergence is not merely a Nordic phenomenon. Elected on a conservative platform in the United Kingdom, Boris Johnson moved to the left on public spending and tax cuts for the working poor, outflanked the right on Brexit and strict immigration policies, and captured the attention of environmentalists by making an ambitious and explicit promise. By 2050, he asserted, England "will no longer make any contribution whatsoever to the destruction of our precious planet brought about by carbon emissions - because we will have led the world in delivering that net zero target." ${ }^{23}$ Across the Channel, Emmanuel Macron found out that neglecting the environmental pillar is costly. In June 2020, France was swept by a green 
wave as ecology candidates won a number of major victories in the country's local elections, sending the national arena an important message about present-day preferences. $^{24}$

The return of the nation-state as a major, long-term, crossgenerational service provider is no longer merely the vision of left-wing progressives or antiglobal nationalists. It is becoming the new consensus. Testimonies to the power of this ideological shift come from diverse and seemingly unrelated sources such as BEPS (Base Erosion and Profit Shifting) tax regulations and the Business Roundtable-a collaboration of CEOs of major companies in the United States. Both declare that we must enlarge the income base of states in order to be able to meet social needs, not only of this generation but also of future ones.

The 2020 Irish elections are a striking example of this change of priorities. Despite the fact that globalism allowed the Irish economy to enjoy exponential growth of foreign investments, Mary Lou McDonald, head of the nationalistic party of Sinn Féin, managed to attract a historic level of support by campaigning on a platform addressing problems of housing affordability and health-care services, overthrowing the neoliberal prime minister, Leo Varadkar. The vote was an expression of the desire to withdraw from the neoliberal credo, demanding that the state should secure long-term goods rather than cheap commodities. What the election shows, Fintan O'Toole argues, is that "even for the winners, the existing model of free market globalization is deeply flawed: it cannot produce, even in a rich society, the public goods that citizens expect." ${ }^{25}$

Down under, similar trends developed. In 2017, Jacinda Ardern, the leader of the Labour Party, formed a coalition government with the "New Zealand (NZ) First" right-wing party, and the Green Party. Explaining his party's alliance with Ardern, the head of New Zealand First, Winston Peters, said, "'For too 
many New Zealanders, capitalism has not been their friend but their foe,' . . claiming vulnerable New Zealanders had been left behind while the political elite got richer. 'We believe capitalism must regain its human face, and that conviction deeply influenced our decision.'"26 The coalition's agreed-upon goals reflected the convergence of national, social, and environmental goals: improving the lives of New Zealand's most vulnerable people, pledging to wipe out child poverty and to make tertiary education free, reducing immigration, introducing a water tax, and making all rivers swimmable within ten years. ${ }^{27}$

Ardern is a vivid example of a compassionate leader. No one doubts her commitment to fight social injustice and global warming. She seeks social integration of minorities and defends their rights. Following the 2019 Christchurch massacre in which fifty-one Muslims were killed, the pictures of her with her head covered, visiting the mosque and the victims' families became iconic. As an act of sympathy, Ardern declared the abolition of policies restricting refugees who originate in Middle Eastern and African states from settling in New Zealand. Shortly after, she had to reverse this decision and again limit the number of refugees from the Middle East and African countries. This is no coincidence. Balancing tight immigration laws with policies meant to support the integration of already existing minorities and original peoples distinguishes the new convergence from right-wing coalitions. The former see laws of entry as a way of protecting an inclusive community; the latter, as a way of separating "us" from "them."

In welfare states, entry grants privileges. It is therefore natural for such states to be cautious about their admission policies: Australia, Canada, and New Zealand select their immigrants carefully. Similarly, Finland, Denmark, and Norway endorse strict immigration policies. States like Sweden and Germany 
that, for a while, opened the door too wide had to make a political U-turn and admit that unlimited immigration and generous welfare policies are unlikely to coexist. ${ }^{28}$ In other words, social democratic welfare states wish to control who and how many "join the club," and while they are careful not to incite against others (minorities, immigrants, refugees, and asylum seekers), they demand integration and enforce it quite vehemently.

The confluence of immigration, welfare, and environmental policies leads to the formation of a new social contract that is both horizontal (cross-classes) and longitudinal (crossgenerations). Putting its members first, it places national interests before global ones, leans toward protectionism, and prefers state intervention over laissez-faire policies. It therefore appeals to nationalists and social democrats alike and draws the attention of environmentalists who understand that present-day investments in protecting the future of the planet require the formation of transgenerational commitments. In other words, the above-mentioned convergence is not the outcome of a coincidental and momentary overlap of ideas. Its supportive pillars form a cohesive political approach that stresses the importance of a "chain reaction": Systems of distributive justice demand trust; collective, continuous, cohesive identity promotes trust; collective, continuous, cohesive identity depends on a certain degree of exclusion and demarcation. Demarcation gains legitimization from some overarching principles - in the case of the modern nation-state, it is grounded in a combination of national and democratic values. Nationalism then, may be frivolous about its partners; long-term, distributive democratic theory has fewer choices. It is naturally drawn to nationalism's arms.

The main questions the new convergence answers are basic ones: who owes what to whom and when? The "who" element 
refers to fellow citizens - to whom we have special obligations in terms of the social contract between us. The "what" element refers to redistributive policies meant to counter damages induced by hyperglobalism and neoliberalism that led to a shift of responsibility from the state to individuals. Resenting this transference of responsibilities, citizens now demand that their nation-state must help them out. They feel less gratified by "the lowering of prices of discretionary goods and services as a result of free trade and are more concerned about basic necessities such as housing, health care, pensions, and educationstate-related services that absorb an ever-growing proportion of their income." ${ }^{29}$ This demands additional national resources, hence the proliferation of calls to tax mega-companies and impose a wealth tax or an inheritance tax to boost national income. The "when" pillar defines the time frame of the social contract. It includes a firm commitment to offer future generations a safety net, ensuring them the largest possible set of opportunities in return for their investment in the well-being of present generations (especially the elderly).

Be it from the right (like Kurz, Johnson, and McDonald) or the left (like Frederiksen, Löfven, and Ardern), seizing political power is easier for those dominating the convergence zone. For progressive, democratic forces, welfare and environmental policies are easy to stomach, but not the new national tune recently added to the musical sequence. Yet the key to success is leaving no pillar out: to acknowledge the importance of a continuous (transgenerational) social contract that places the nation-state at the center of social, economic, and environmental activities, and stresses a commitment to put fellow nationals first.

Is the convergence theory applicable to the United States? Nationalist undertones are certainly heard across the country. Trump openly plays the nationalist card, demonizing immigrants 
and making them scapegoats. An inclusive alternative that offers a path to citizenship for undocumented immigrants alongside a slowdown of future immigration is yet to emerge. ${ }^{30}$

The other two pillars - the social and environmental onesare quite forgotten. The United States is certainly not a welfare state, yet the pandemic changed the rules of the game. Many of those suspicious of any kind of intervention of the federal state are now eagerly awaiting its support. Even the people of the heartland who, according to Arlie Hochschild, developed a visceral hate for the federal government, hated other people for needing it, and rejected their own need of it, ${ }^{31}$ are now searching for its supportive hand. The unprecedented rate of unemployment (an unemployment rate of 13.3 percent, equivalent to 21 million registered unemployed persons, was reported in May 2020 $)^{32}$ and the growing medical, social, and economic crisis sent Trump and his administration searching for ammunition that goes beyond their standard arsenal. Realizing the scale of the damage caused by the pandemic, the administration offered trillions of dollars in support programs, and yet there is no mention of welfare rights, no attempt to legislate or build social services and institutions, no sign of turning emergency steps into an ongoing policy.

While capitalism is under scrutiny even from its main supporters, a socially oriented position has yet to be articulated. In June 2020, the New York Times published a series of such articles under the title "The America We Need." A new discourse is emerging and waiting to be politically employed. The third (the environmental) pillar must also not be ignored. Against making American Great Again, we need to develop a new social contract, based on the Great Society principles, that covers the sphere of convergence and offers a social and political vision relevant for this time and age. 


\section{The Coronavirus Pandemic and the National World Order}

The age of convergence started before the Corona pandemic changed our lives. Trends that started crystalizing before the pandemic were accelerated by it. The three converging pillars: national solidarity, social responsibility, and environmental concerns all became more relevant than ever.

The pandemic raised the consciousness of the first world concerning the dangers embedded in social, economic, and medical uncertainty, and has forced individuals to reexamine their political, economic, and social paradigms. The first, and most surprising, lesson is that although the pandemic is a global phenomenon, it reinforces the notion of national sovereignty. The virus does not recognize national boundaries, yet the struggle against it reflects a distinctly national state of mind. One by one, nation-states closed down their borders, taking measures to protect their citizens, putting their own countries first.

Faced with prospect of numerous victims at home, countries physically separated their citizens from all others. The medical logic of such policy is flimsy: an Italian from Milan is probably geographically, economically, commercially, culturally, and personally closer to a Swiss from Lausanne than to a compatriot from Sicily. A more effective strategy might have been to ignore national boundaries and map social and economic interactions. And yet national sentiments prevailed, proving once again that in times of crisis, fellow nationals stick together.

Others-in this case, those residing outside national borders - turned into a threat. Italy was the first European country to confront the pandemic. In response, it closed its borders, not only to those coming from China but also to the citizens of its neighboring countries. Spain, Austria, Poland, the 
Czech Republic, Switzerland, Georgia, and Russia followed; even Emmanuel Macron, one of the European Union's greatest champions, came around. Initially declaring that the virus "has no passport" and is devoid of national characteristics, he failed to withstand the pressure and joined the national choir. Now, he said, "is the time for protecting our fellow citizens and for the Nation's cohesion. It's the time for that sacred unity which consists in following the same path together, not panicking, being afraid or complacent, but regaining that strength of mind which has enabled our people to overcome so many crises throughout history." 33 Angela Merkel also gave in. At first, she preached for the maintenance of open borders, but within days, she too succumbed to fear and closed Germany's borders with its neighbors. Prime Minister Justin Trudeau of Canada announced that he was closing the borders to foreigners, with the exception of US citizens. "It is time to take every precaution to keep people safe," he said. ${ }^{34}$ Soon after, on March 18, 2020, together with President Donald Trump, he agreed to close the border between their two countries in order to help contain the spread of the virus. At the very same time, Trump announced that the US-Mexico border would also shut down.

International organizations in general and the European Union in particular were late to respond. By the time the EU decided to close its borders, the national horses had bolted the stable, and it had no choice but to agree retroactively that every country should define its own policy. The Schengen Agreement (which created intra-European freedom of movement) was put to the test and failed. The status of the Union was further eroded when Italy and Spain requested the issuing of coronavirus bonds as a new debt instrument, combining securities from different countries to mitigate the vast economic impact of the pandemic. The initiative was at first opposed by Germany and 
the Netherlands. What is the EU good for, if it cannot help us now?, Italian officials asked.

In each of the countries facing the crisis, a common ritual developed: appearing against the backdrop of the national flag, leaders addressed their citizens, announcing the latest restrictions alongside prospective support plans and concluding with encouraging words: "We are strong," "We stand together," and of course, "God bless our nation." Nothing defines the moment better than Queen Elizabeth II's speech to her nation on April 6, 2020. With her son Prince Charles in quarantine and her prime minister, Boris Johnson, in emergency care, she addressed the British people (echoing other national speeches made at times of national crisis). "I hope," she said, "in the years to come, everyone will be able to take pride in how they responded to this challenge. And those who come after us will say the Britons of this generation were as strong as any. That the attributes of self-discipline, of quiet good-humoured resolve, and of fellow feeling still characterise this country. The pride in who we are is not a part of our past, it defines our present and our future." 35

Even the battered Italians wrapped themselves in their tricolor flag while standing on their balconies singing the national anthem. National solidarity did not end with flag waving. The pandemic sharpened the importance of nationwide services capable of coping with emergencies: airlines; emergencyresponse forces; health-care, education, and public transportation systems all turned into national assets. The nationalization of an airline suddenly seemed like a reasonable move, as did the partial and temporary takeover of hospitals, pharmaceutical supply chains, and other means of production. And, if the economic crisis worsens, states may also consider controlling private services such as cash machines, pharmacies, and supermarkets. 
The economic crisis that follows the medical one also requires states to become active players in the employment sector, in labor relations, and in supporting the growing number of unemployed and laid-off workers. States are required to decide who is to be saved, in what manner, and for how long. In sharp contrast to the 2008 financial crisis, this time the bailout involves generous public funding that targets working people rather than banks.

The age in which scholars and elected officials criticized public services for being too expensive, inefficient, and often corrupt seems to be over. Nowadays people stand on their balconies applauding and cheering physicians, nurses, sanitation workers, and other caregivers who not long ago were at the bottom of the social respect scale. Many of these workers are lower-middleclass women, members of minority groups, who in everyday life hardly make it to the end of the month. Now they are our heroes. Don't be surprised if in the post-pandemic era there will be a special bill (inspired by the G.I. bill) to support people in these professions and motivate others to join them.

The present pandemic makes it clear that without solid (and generous) public services, states will not be able to survive. The social and economic price of thin states lacking national health systems and federally managed educational systems is starting to be acknowledged. The fact that 30 million Americans do not have health insurance and a similar number of workers do not have paid sick leave is turning into a national problem. The dramatic weakening in Britain of the National Health Service presents a challenge to Johnson's government and the whole of the British people, just as Italy is now paying an enormous price for its lack of public planning.

The severity of the pandemic is inducing governments to change their policies. Until recently, the test of a government's financial stability was the level of its national debt. Now it is 
its ability to provide solid universal health services and a working educational system, to kick-start the economy, to increase people's buying power, and to create new jobs. The message is sinking in rapidly; conservatives, socialists, and centrists alike all wrangle over who will transfer more resources to those in need. The "invisible hand" has vanished. The nation-state's active role in coping with economic, social, and health crises is evident.

Ironically, the international nature of the plague makes clear that there is no escape, nowhere to go. With borders closing down one after the other, and visas hard to get, high-flying globetrotters have to face the reality that their survival depends, to a large extent, on their home state and the services it provides. Health turned from a personal good to a collective one. Even those who seek refuge in their mansions are likely to cross paths with others exposed to the pandemic. In short, if your compatriots' lives are in danger, so is yours.

The fact that royals and celebrities were among the first to be diagnosed with the coronavirus reinforced already existing antielitist attitudes. Headlines around the world characterized the coronavirus as the plague of the snobs. The Los Angeles Times ran a story reporting that some of Mexico's richest residents went to Colorado to ski and brought home the virus. ${ }^{36}$ The Uruguayan press followed the fashion designer Carmela Hontou, who caught the virus in Madrid and came back to infect people while attending a wedding party. The headline was "Uruguay Thought Coronavirus Had Passed It by until a Wealthy Socialite Came Home from Europe." ${ }^{37}$ The New York Times criticized the fact that celebrity patients received privileged access to testing.

In Germany, "Der Westen ran an article under the inflammatory headline: 'The Superrich and the Corona Virus: Billionaires and Their Antisocial Behavior.' The article cites a Twitter 
message that claimed that the best way for an average American to find out if they have Covid-19 is to cough in a rich person's face and wait for their victim's test results." 38 The Guardian claimed that "the world's richest people are chartering private jets to set off for holiday homes or specially prepared disaster bunkers in countries that, so far, appear to have avoided the worst of the Covid-19 outbreak." ${ }^{39}$ Meanwhile, the list of infected celebs kept growing. Worst of all, as more poor people are affected and dying from the virus, the image of an infectious elite spreads rapidly, inciting the already existing class war.

The fact that the virus started in Hunan, which is an economically developed and rapidly growing region of China, and spread to the richest parts of northern Italy made it clear that the category of the vulnerable expands to include members of all classes. It's too early to tell if class hostility or solidarity will prevail. One thing is certain: the wealthy will have to endure much of the rage that the pandemic sparks, and they will have to foot much of the bill. Tax planning and tax shelters will go out of fashion. Coronavirus taxes may become the order of the day. The independence of the mega-corporations will be limited - and they too will be obliged to contribute their share. Some have already started to send the public messages attesting to their heightened sense of responsibility. The Business Roundtable manifesto that redefined the purpose of responsible corporations to be the promotion of an economy that serves all Americans is changing business culture, moving from a stakeholders to shareholders alliance. Recently, Starbucks published a statement detailing the measures it is adopting for the economic protection of its employees during the temporary closure of its branches. Other companies are likely to follow.

While not ignoring the disastrous effects of the pandemic, we can take solace in the fact that the epidemic has brought about 
a situation that many other events have failed to achieve. It has placed at the center of the political stage a civic-territorial kind of nationalism that sees the protection of its citizens as its first priority. One can only hope that this new state of affairs will reinforce the inclusive structure of nation-states, boosting their national solidarity and legitimizing the welfare state, while also fostering a desire to forge international cooperation across national borders. Surprisingly then, the coronavirus may succeed in making moderate civic nationalism a viable option. We have a lot of reasons to be fearful but also some grounds for hope.

\section{Notes to Preface to the Paperback Edition}

1. Quoted in William Cummings, “'I Am a Nationalist': Trump's Embrace of Controversial Label Sparks Uproar," USA Today, October 24, 2018.

2. Kim R. Holmes, “The Problem of Nationalism," Heritage Foundation, December 13, 2019, https://www.heritage.org/conservatism/commentary/the-problem -nationalism.

3. Michael Walzer, Exodus and Revolution (Oxford: Oxford University Press, 1985).

4. Eva Cossé, "The Alarming Rise of Anti-Semitism in Europe: European Governments and Public Should Stand Up against Hate," Human Rights Watch, June 4, 2019, https://www.hrw.org/news/2019/06/o4/alarming-rise-anti-semitism-europe.

5. Enes Bayrakli and Farid Hafez, eds., European Islamophobia Report 2018, SETA: Foundation for Political, Economic and Social Research, 2019), https://www .islamophobiaeurope.com/wp-content/uploads/2019/o9/EIR_2018.pdf.

6. Norimitsu Onishi, “George Floyd's Killing Forces Wider Debate on France's Slave-Trading Past,” New York Times, June 24, 2020.

7. BBC, "Princeton to Remove Woodrow Wilson's Name from Policy School," June 28, 2020.

8. Onishi, "George Floyd's Killing Forces Wider Debate."

9. Ibid.

10. David Nakamura, Seung Min Kim, and James McAuley, "Macron Denounces Nationalism as a 'Betrayal of Patriotism' in Rebuke to Trump at WWI Remembrance," Washington Post, November 11, 2018.

11. Ibid.

12. Aira Kemiläinen, "The Idea of Patriotism during the First Years of the French Revolution," History of European Ideas 11 (1989): 11. 
13. Yael Tamir, Liberal Nationalism (Princeton, NJ: Princeton University Press, 1993), chap. 5 .

14. Yael (Yuli) Tamir, "Not So Civic: Is There a Difference between Ethnic and Civic Nationalism?, Annual Review of Political Science 22 (May 2019): 419-34.

15. Quoted in Onishi, “George Floyd's Killing Forces Wider Debate.”

16. Quoted in Yascha Mounk, The People vs. Democracy: Why Our Freedom Is in Danger and How to Save It (Cambridge, MA: Harvard University Press, 2018), 209-10.

17. Quoted in Phil Hoad, "Corrupt, Dangerous and Brutal to Its Poor-but Is Marseille the Future of France?," Guardian, June 8, 2017.

18. Christophe Chowanietz, Bombs, Bullets, and Politicians: France's Response to Terrorism (Montreal: McGill-Queens University Press, 2016), 196n.143.

19. Ana Swanson and Emily Cochrane, "Trump Signs Trade Deal with Canada and Mexico," New York Times, January 29, 2020.

20. Stephen M. Walt, "You Can't Defeat Nationalism, So Stop Trying," Foreign Policy, June 4, 2019, https://foreignpolicy.com/2019/o6/04/you-cant-defeat -nationalism-so-stop-trying.

21. Holmes, "The Problem of Nationalism."

22. Johan Sennero, "Swedish PM Stefan Lofven Wins Second Term," Reuters, January 18, 2019, https://www.theglobeandmail.com/world/article-swedish-pm -stefan-lofven-wins-second-term-ending-four-month-political.

23. Fiona Harvey, “Johnson Urged to Set Out Firm Plans for UK's Net-Zero Carbon Target," Guardian, February 6, 2020.

24. Kim Willsher, "Greens Surge in French Local Elections as Anne Hidalgo Holds Paris,” Guardian, June 28, 2020.

25. Fintan O'Toole, "Ireland's Shock Poll Result Was a Vote against the Success of Globalism," Guardian, February 16, 2020.

26. Quoted in Eleanor Ainge Roy, "How Reluctant Leader Jacinda Ardern Charmed New Zealand," Guardian, October 19, 2017.

27. Eleanor Ainge Roy, "Jacinda Ardern to Be New Zealand's Next PM after Labour Coalition Deal," Guardian, October 19, 2017.

28. Exceptions are made when states need workers or for demographic reasons must recruit young people. In such cases, states are ready to offer incentives to bring people in (but only the kind of people who meet their needs). Changing immigration policies in Japan are an example of the way that demographic changes alter immigration policies.

29. James Manyika et al., The Social Contract in the 21st Century, McKinsey report, February 5, 2020, https://www.mckinsey.com/industries/social-sector/our-insights /the-social-contract-in-the-21st-century.

30. David Leonhardt, “The Simple Reason the Left Won't Stop Losing," New York Times, March 8, 2020. 
31. Arlie Russell Hochschild, Strangers in Their Own Land: Anger and Mourning on the American Right (New York: New Press, 2016), 151.

32. US Department of Labor, Bureau of Labor Statistics, June 5, 2020.

33. "Statement to the French People by M. Emmanuel Macron, President of the Republic, on the COVID-19 Coronavirus," French Ministry for Europe and Foreign Affairs, Official Speeches and Statements, March 16, 2020, https://franceintheus.org /spip.php?article9654.

34. Jen Kirby, "Canada Imposes Strict Entry Restrictions to Slow Coronavirus Spread," Vox, March 16, 2020.

35. BBC, “Coronavirus: The Queen's Broadcast in Full," April 5, 2020, https:// www.bbc.com/news/uk-52176208.

36. Kate Linthicum, "Some of Mexico's Residents Went to Colorado to Ski. They Brought Home Coronavirus," Los Angeles Times, March 20, 2020.

37. Sarah Smith, "Uruguay Thought Coronavirus Had Passed It by until a Wealthy Socialite Came Home for Europe," Zenger, March 23, 2020.

38. Rainer Zitelmann, "The Superrich Are Increasingly Coming under Attack during the Corona Crisis," Forbes, April 13, 2020.

39. Rupert Neate, "Super-rich Jet off to Disaster Bunkers amid Coronavirus Outbreak," Guardian, March 11, 2020. 